\title{
Conservation of superior Egyptian date palm genotypes through in vitro culture of inflorescence explants
}

\author{
Abul-Soad A.A. ${ }^{1}$, A. S. Abdallah ${ }^{1}$, O.A. Khalil ${ }^{1}$ and Shiamaa M. Mahdi ${ }^{2}$ \\ ${ }^{I}$ Tropical Fruit Department, Horticulture Research, Institute, Agricultural Research Center, Giza, Egypt \\ ${ }^{2}$ Bioassay Department, Central Agricultural Pesticides Laboratory (CAPL), Agricultural Research Center, \\ Giza, Egypt
}

\begin{abstract}
Using floral buds could help to conserve the date palm biodiversity and finding a way to rapidly multiply the landraces with socioeconomic value. Siwa oasis in Egypt can be considered as biodiversity center of date palm. Several competitive date palms emerged from seeds, a variety at risk of distinction named "Ghazal" and top commercial variety 'Siwy' were selected based on fruit phenotype and evaluated. Upon flowering an immature spathe was technically excised from each parent tree and transferred to the laboratory for micropropagation. The in vitro plantlets of these endangered and superior genotypes were obtained within a single year. The steps carried out to achieve this target were described and discussed in the current study.
\end{abstract}

Keywords: Micropropagation; Floral buds; Biodiversity; Date palm

\section{Introduction}

The largest date palm producers in the world in 2014 were Egypt (1,465,030 tons), followed by Iran (1,156,996 tons) and Algeria (934,377 tons). Regarding date palm cultivated area, Iraq has the largest area, with 242,632 hectares, followed by Algeria (165,378 ha) and Iran (150,207 ha) as reported by FAO (2017); Ribeiro et al. (2020). In vitro propagation of date palms has been widely studied in several countries (Abul-Soad and Mahdi, 2010; Aslam et al., 2011; Eldin and Ibrahim, 2015), including the use of inflorescence segments as explants (Zayed et al., 2016; Ribeiro and Teixeira, 2017; Ribeiro et al., 2020). Date palm (Phoenix dactylifera L.) is an economic crop in

\footnotetext{
*Corresponding author: Abul-Soad, A.A.

Email: adelaboelsoaud@gmail.com

Received: March 18, 2021;

Accepted: April 11, 2021;

Published: April 15, 2021.
}

Egypt and other countries with nourishing fruit. All over Egypt, one can find dispersed single trees with distinguishable fruits similar or superior to current commercial cultivars but, no powerful (innovative) way to almost multiply them due to no presence of the offshoots. This leads to demolish and loss of such valuable individual trees made by the nature and more adaptable with the local environment. Siwa oasis is one of date palm biodiversity centers in Egypt. In order to conserve superior genotypes, i.e. lines and support the biodiversity, there was a need to multiply them rapidly. Inflorescencebased micropropagation holds great potential for the multiplication of recalcitrant male (ElKorchi 2007) and female (Abahmane, 2007; Abul-Soad, 2011 and 2012; Abul-Soad et al, 2004; Drira and Al-Shaary, 1993) date palm individual trees and commercial cultivars with limited populations. This can be accomplished in a short time with minimal effort as compared to the traditional practice of using shoot-tip 
explants of the small offshoots (Abul-Soad and Mahdi, 2010). Nevertheless, regeneration through somatic embryogenesis or organogenesis in date palm is still difficult to achieve for recalcitrant genotypes and is often hampered by certain physiological disorders (Mazri and Meziani, 2015). The aim of this research study is to pave the way to use the inflorescence explants to micropropagate superior date palm genotypes in Siwa oasis including those at risk of distinction. This supports the biodiversity and development of Egyptian oasis where such genetic resources were growing.

\section{Materials and Method}

This work has been carried out in Siwa oasis and tissue culture laboratory of Horticulture Research Institute (HRI) in Giza, Egypt in between 2014-2016. The following steps were performed:

1. Two valuable genotypes derived from seeds of date palm was selected at the time of fruiting in October, 2014 from Siwa oasis and given names Siwa_1 and Siwa_2. This in addition to an endangered cultivar of 'Ghazal' and top commercial cultivar of Egypt 'Siwy'.

2. The collected fruit samples of these superior genotypes were evaluated via physical and chemical analysis.

3. An immature inflorescence was excised from each parent tree in February 2015.

4. The excised plant materials transferred to the lab. in Giza after 2-3 days.

5. Spikelet explants were sterilized under aseptic conditions and established in vitro.

6. The in vitro shoots were obtained by Oct., 2015

7. In vitro shoots were multiplied in early 2016.

\section{Parent trees selection and fruit measurements}

The method to select a superior line was to inquire from the experts whether they were date palm specialists, growers or even laborers about the superior genotypes. Then the team went to the place to explore the parent tree productivity and fruit quality. After collecting fruit samples from the desired date palm cultivars and superior female lines, digital photos for the fruit shape were taken. With the help of graduated tape, the whole fruit at ripening stage, longitudinal and transverse sections and ventral and dorsal sides of the seed were presented in the photo (Fig. 1). The physical characteristics of the fruit were measured as an average of 10 fruit sample. These measures were presented in the Table 1 .

\section{Fruit chemical analysis}

A homogenized fruit sample was used in a chemical analysis to determine the main fruit constituents such as total sugar content, reducing and non-reducing sugars, moisture content $(\%)$, tannins $(\mathrm{mg} / 100 \mathrm{~g})$, acidity, fibers $(\%)$ and nitrogen content (\%). These constituents were measured in the pulp tissue according to Lane and Eynon volumetric procedure as outlined in A.O.A.C (1985), Table 2. This analysis has been carried out by a specialized lab. at HRI

\section{Fruit evaluation process}

The most important characters could be the high fruit weight, low seed weight and high sugar content. Based on the method described by Hussein et al. (1982) and Moustafa et al. (1986), the evaluation of the fruit quality of every tested genotype was calculated on the basis of 100 units which were divided up among the various fruit properties (Table 3 ). Each genotype gave the best result in any character was given the "full mark" which specified for this character, while each of the other tested cultivars took lower units equal to their qualities as a percentage from the best 
genotype. 'Siwy' cv. was used here as a control to make a comparison with other genotype .

\section{Immature inflorescence excision and transfer to the laboratory}

An ax, cutter and rope were the means used by the laborer during the process of excision. The process of immature spathe excision has been successfully applied in Pakistan in 2011 (AbulSoad, 2011) and applied in Egypt through current project. The steps were as follows:

1. The frond in which the immature spathe was expected to be existed was shortened by pruning the terminal half as a sign.

2. Two to three fronds beneath the defined frond were pruned entirely (Fig. 2).

3. The brown fibers covering the base of the shortened frond was carefully cut from both right and left sides with cutter.

4. The immature spathe which was mostly adjoined to the shortened frond was detached with the help of a sharp cutter and was brought down to the ground (Fig. 3).

5. The length and width were measured after the surface has been cleaned by a piece of paper tissue or cotton.

6. The excised immature spathe was kept in an ice tank and transferred to the lab. in the next few days.

7. The place from where the spathe has been taken was treated with a pesticide, Malathion.

\section{In vitro establishment}

Before to bring the explants from Siwa oasis (700 Kilometers away from the laboratory at Giza governorate), the following nutrient medium for starting was prepared:

MS basal salts with vitamins (Murashige and Skoog Medium, 1962) $+30 \mathrm{~g} \mathrm{l}^{-1}$ Sucrose +2.2 $\mathrm{g} \mathrm{l}^{-1}$ Agar $+1.4 \mathrm{~g} \mathrm{l}^{-1}$ Gelrite supplemented with (in $\mathrm{mg} \mathrm{l}^{-1}$ ): $170 \mathrm{KH}_{2} \mathrm{PO}_{4}+100$ Glutamine +40 Adenine Sulfate + 0.1 2.4-D + 0.1 IAA + 5.0 NAA (a modified medium of Abul-Soad and
Mahdi, 2010). Media was prepared in test tubes and large jars. Media was stored for a week before usage.

\section{Surface sterilization procedure}

1. The intact spathes have been carefully washed with tap water upon arrival to the lab (Fig.3).

2. Name of the genotype was written on the outer sheath of everyone by a permanent marker.

3. All spathes were placed in a plastic box and immersed in sodium hypochlorite solution at $30 \%$ for 10 min. with few drops of Tween-20.

4. Spathes were washed with sterilized water 3 times and placed in antioxidant solution of citric (100 $\left.\mathrm{mg} \mathrm{l}^{-1}\right)$ and ascorbic acid (150 mg $\left.1^{-1}\right)$ till culture under aseptic condition.

The initial explants of spikelets were cultured onto the establishment nutrient medium. The test tubes were rapped with parafilm after culture. Then all cultures were covered with a black sheet and placed in the dark growth room. Fungal and bacterial contamination was monitored from time to time and contaminated explants were discarded. After surface sterilization, the explants were subcultured every 3-4 weeks for 3-4 subcultures till embryogenic calli induced and differentiated into somatic embryos.

\section{In vitro shoots multiplication}

The differentiated somatic embryos were left for 2-3 months till fully mature. Then the multiple structures were shifted to the next stage of multiplication onto the previous basal medium supplemented with $0.1 \mathrm{mg} \mathrm{l}^{-1}$ Naphthalene Acetic Acid (NAA) and 0.05 6Benzyleamino purine (BA).

\section{Statistical analysis}

Data were statistically analyzed and the significant differences among means were 
tested using L.S.D.at $0.5 \%$ and the standard error was estimated (Steel et al., 1997).

\section{Results and Discussion}

\section{Parent trees selection and fruit evaluation}

The inflorescence explants have been successfully used outside Egypt to micropropagate a number of Pakistani cultivars for commercial (Abul-Soad, 2011; Abul-Soad and Mahdi, 2010; Jatoi et al., 2015), and the current study aimed to apply such useful technique in a complete program to explore and conserve Egyptian elite and endangered cultivars of limited population in the date palm centers of Egypt including Siwa oasis.

After selection of a number of superior genotypes of date palm in Siwa oasis. From among them the selected individuals were given names indicated the places from where they have been collected or the already names have been given by trees' owners. Measured fruit physical characters showed that Siwa_2 has a significantly heavy fruit weight of 20.6 grams/fruit at edible stage of early tamer compared to Siwa_1 and Ghazal genotypes (Table 1). Also, it had a jumbo fruit size of 6.0 $\mathrm{cm}$ long and $2.6 \mathrm{~cm}$ wide. Although the fruit dimensions matters, but the taste and shape of fruit in terms of skin wrinkles (shriveling) in addition to the color are also important traits. There were wrinkles on both Siwa_1 and Ghazal made their fruit appeared shiny and has an attractive look (Fig. 1 a,b). However, the three genotypes had a distinctive and desirable taste. Fruit samples of these three genotypes particularly were presented during the proceedings of the first dates' festival in Egypt which held from 8-10 Oct., 2015 at Siwa oasis. Anticipating the opinion of the visitors about the quality of these genotypes assisted the evaluation of these genotypes. These were the most important measures found to be taken in the literature. Therefore, this type of photography would assist good description of fruit quality.

A chemical analysis was conducted for dates fruit of targeted genotypes. A complete profile for the possible constituents was presented in Table 2. The obtained results indicated that the total sugars content in the fruit were significantly different as were 55.7, 43.9 and $29.6 \%$ of fruit dry weight for Siwa_1, Siwa_2 and Ghazal genotypes. Therefore, the amount of non-reducing sugars (sucrose) was higher than reducing sugars as the fruit entered tamer stage. The Siwa_1 genotype proved to have the sweetest fruit where the total sugars was $55.7 \%$. Other fruit constituents measured showed that no significant difference were found in acidity, but the tannins, fibers and nitrogen content of the three genotypes varied significantly. Presence of a high fiber content $(6.26 \%)$ in Siwa_1 genotype could impact positively the human health. However, the test of the later genotype fruit was very good. Furthermore, the high percentage of fruit moisture content in Siwa_1 (30.7\%) compared to other genotypes can explain why fruit were chewy. Determining the nutritional value of the targeted genotypes fruit was necessary to give a comprehensive picture for their economic value, but on scientific bases.

The relative evaluation of the Siwa date palm genotypes compared to the top commercial cultivar of Egypt (Siwy) was summarized in Table (3). Data revealed that the Siwa_2 genotype gained the maximum fruit weight (29 grams/fruit) and harvested the highest units with 94.4 units exceeding the best commercial variety in Egypt Siwy (92.2 units) in terms of export and local consumption. It is followed by Siwa_1 genotype with 92.6 units. Thus these two superior genotypes were selected. This is in addition to the var. "Ghazal" which is an endangered cultivar with very limited population of 4-5 female trees in late age (Fig. 
1c). Thus, the total number was two female lines, one endangered cultivar and a single tree of Siwy from Siwa oasis. Eventually and based on the physical and chemical fruit characteristics and investigations done with experts, two female lines, one endangered cultivar and a single tree of Siwy from Siwa oasis have been selected and subjected to the inflorescence excision process during flowering season of 2015.

Table 1. Fruit physical characteristics at Tamer stage $\mathrm{z}^{\mathrm{z}}$ of the selected superior genotypes of date palm grown at Siwa oasis in Oct. 2014.

\begin{tabular}{llllllll}
\hline $\begin{array}{l}\text { Selected } \\
\text { Female Name }\end{array}$ & $\begin{array}{l}\text { Fruit weight } \\
(\mathbf{g})\end{array}$ & $\begin{array}{l}\text { Seed weight } \\
\text { (g) }\end{array}$ & $\begin{array}{l}\text { Flesh } \\
\text { weight }(\%)\end{array}$ & $\begin{array}{l}\text { Fruit } \\
(\mathbf{c m})\end{array}$ & $\begin{array}{l}\text { Fruit width } \\
(\mathbf{c m})\end{array}$ & \\
\hline Siwa_1 & $14.9^{\mathrm{y}} \mathrm{b}$ & $1.0 \mathrm{~b}$ & $13.9 \mathrm{~b}$ & $5.5 \mathrm{~b}$ & $2.1 \mathrm{c}$ & \\
Siwa_2 & $20.6 \mathrm{a}$ & $1.5 \mathrm{a}$ & $19.1 \mathrm{a}$ & $6.0 \mathrm{a}$ & $2.6 \mathrm{a}$ & \\
Ghazal & $12.6 \mathrm{c}$ & $1.5 \mathrm{a}$ & $11.1 \mathrm{c}$ & $4.4 \mathrm{c}$ & $2.4 \mathrm{~b}$ & \\
S. E. & $\mathbf{5 . 8 9}$ & $\mathbf{0 . 4 2}$ & $\mathbf{5 . 6 6}$ & $\mathbf{1 . 1 6}$ & $\mathbf{0 . 4 3}$ & \\
\hline
\end{tabular}

Numbers followed by same letters are not significant at 0.05 (LSD). z: the edible stage. y: All measures are average of a 10 fruit sample, S.E. ( the standard error).

Table 2. Fruit chemical constituents of the selected superior 'Siwa_1', 'Siwa_2' and 'Ghazal' date palm at Tamer stage from Siwa oasis.

\begin{tabular}{|c|c|c|c|c|c|c|c|c|}
\hline $\begin{array}{l}\text { Selected } \\
\text { Female } \\
\text { Name }\end{array}$ & $\begin{array}{l}\text { Total } \\
\text { sugars }^{\mathrm{z}} \\
(\%)\end{array}$ & $\begin{array}{l}\text { Reducing } \\
\text { sugars }^{\mathrm{y}} \\
(\%)\end{array}$ & $\begin{array}{l}\text { Non- } \\
\text { reducing } \\
\text { sugars }^{x} \\
(\%)\end{array}$ & $\begin{array}{l}\text { Moisture } \\
\text { content } \\
\%\end{array}$ & $\begin{array}{l}\text { Tannins } \\
\text { mg/100g }\end{array}$ & Acidity & $\begin{array}{l}\text { Fibers } \\
\%\end{array}$ & $\begin{array}{l}\text { Nitrogen } \\
\%\end{array}$ \\
\hline Siwa_1 & $55.7 \mathrm{a}$ & $22.4 a$ & $33.3 \mathrm{a}$ & $30.7 \mathrm{a}$ & $10.3 \mathrm{a}$ & $0.013 a$ & $6.26 a$ & $1.08 \mathrm{a}$ \\
\hline Siwa_2 & $43.9 b$ & $20.3 b$ & $23.6 b$ & $15.2 b$ & $6.8 \mathrm{~b}$ & $0.011 b$ & $3.71 b$ & $0.43 b$ \\
\hline Ghazal & $29.6 c$ & $19.2 b$ & $10.4 \mathrm{c}$ & $13.2 \mathrm{c}$ & $10.1 \mathrm{a}$ & $0.012 \mathrm{a}$ & $1.00 \mathrm{c}$ & $0.34 \mathrm{c}$ \\
\hline S.E. & 19.40 & 2.35 & 61.30 & 13.55 & 2.78 & 0.00 & 3.72 & 0.57 \\
\hline
\end{tabular}

Numbers followed by same letters are not significant at 0.05 (LSD),

Steel $e$ tal., 1997. Z: g/100 g dry weight. Y: Glucose and Fructose. X: Sucrose,

S.E. (the standard error).

Table 3. The comparative evaluation units for dates fruit of the Siwa superior date palm genotypes.

\begin{tabular}{cccccc}
\hline Index & $\begin{array}{c}\text { Units } \\
\text { specified }\end{array}$ & Siwa_1 & Siwa_2 & Ghazal & Siwy \\
\hline $\begin{array}{c}\text { Fruit } \\
\text { weight } \\
\text { (gm) }\end{array}$ & 40 & 32.6 & 40 & 18.3 & 32.6 \\
$\begin{array}{c}\text { Flesh } \\
\text { weight (\%) } \\
\text { Total }\end{array}$ & 20 & 20 & 19.7 & 19.2 & 19.6 \\
$\begin{array}{c}\text { sugars (\%) } \\
\text { Total units }\end{array}$ & 100 & 40 & 34.7 & 37.4 & 40 \\
\hline
\end{tabular}

Fruit and flesh weight are measured by gm and total sugars by $\%$. 


\section{Immature Inflorescence excision}

Date palm tree has only a single terminal bud. Decapitating this bud may kill the tree. The bud is protected by the integrated fronds at the top. Once the process of excision you started to be described to a grower, i.e. owner of the parent trees, fears to damage the tree arose and the idea was quickly rejected. The current technique to excise the immature inflorescence is unique and innovative, however, reluctant growers to subject their date palm trees to the inflorescence excision process was one of the main obstacles faced the application in Egypt. So as to resolve this problem through debate to convince them that this process has already been done before, but outside Egypt in Pakistan for many times without a single case of failure. Also, it was explained that this was the only way to rescue their valuable individual trees that don't possess any offshoots can be used as a source for the ordinary propagation. Absence of trained laborers to do the process of inflorescence excision was one of those obstacles too. As there was not a single laborer rather than researcher in the entire country has done this before liking it has proposed in this study. Untrained laborer could damage the parent tree. To mitigate this constraint few abandoned short trees were selected and an excellent date palm laborer was trained before to target the real parent tree (Fig. 2). By this technique it was possible to get immature spathe at very early stage of growth from a single palm has no offshoots and without any damage to the parent tree. The appropriate growth stage of an immature spathe in which it should be excised was identified according to its length (15-20 cm long). However, the length of excised spathes differed and reached up to $50 \mathrm{~cm}$ long (Fig. 3). Age of the immature spathe in terms of length could differ due to few factors including cultivar, ambient climatic conditions, and nutritional state of the parent plants (Abul-Soad, 2011). Appropriate time of excision has to be tested. Care must be paid to treat the wound with fungicide and pesticide to prevent any subsequent infection or infestation from diseases or pests, in particular the red palm weevil. Foliar spray with any available pesticide with bad smell to repel the RPW till the wound tissue dry and heal. "Malathion" pesticide solution at $3 \mathrm{ml} \mathrm{l}^{-1}$ was used. All the targeted trees from which the immature spathe was excised have been checked out after 3 months of excision and found alive (Fig. 4). The follow up process was to keep watching the tree few times around the year which indicated the success of the excision process. The mother tree from which the spathe was excised lost only a single bunch in 2015. In the next year, the wound healed, and tree fruited normally. This could explain how much risky and important to do the process of excision in a proper way by a trained laborer.

\section{In vitro propagation}

The initial explants of spikelet started to produce embryogenic callus after 4 weeks in culture from the florets on the spikelet. These explants showed less browning and good swelling. It was observed that the embryogenic callus produced within the floret itself. Sometimes the entire floret has been replaced by the embryogenic callus (Fig. 5). This usually occurred in the terminal florets on a spikelet. The terminal florets could be composed of less differentiated tissues than the lower ones. It was showed in the anatomical study related to the current work for the female and male florets that terminal florets were less organized than lower basal florets and appeared as a bulk of undifferentiated tissue (Abul-Soad et al., 2016).

Somatic embryos differentiated after 6-8 months from the embryogenic calli. Not all differentiated somatic embryos were suitable to 
be shifted into the multiplication stage. Only the ideal multiple somatic embryos were shifted to a proliferation medium (Fig. 6). The cultures shifted from the tubes into large jars to allow much more growth.

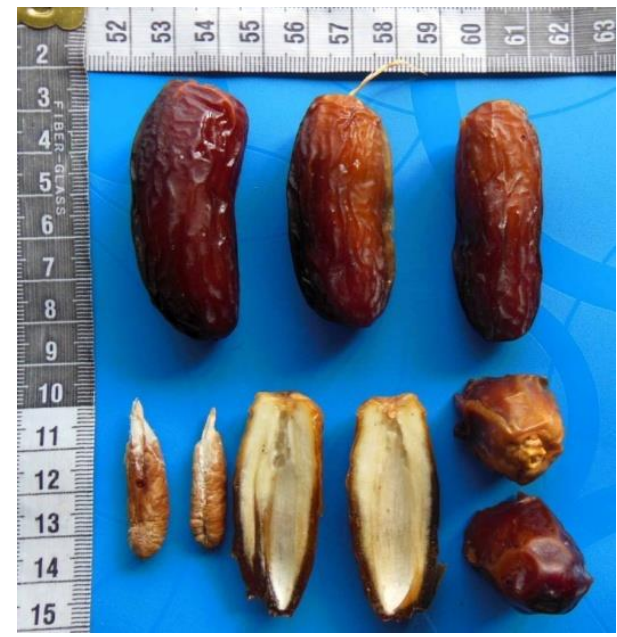

(a) Siwa_1

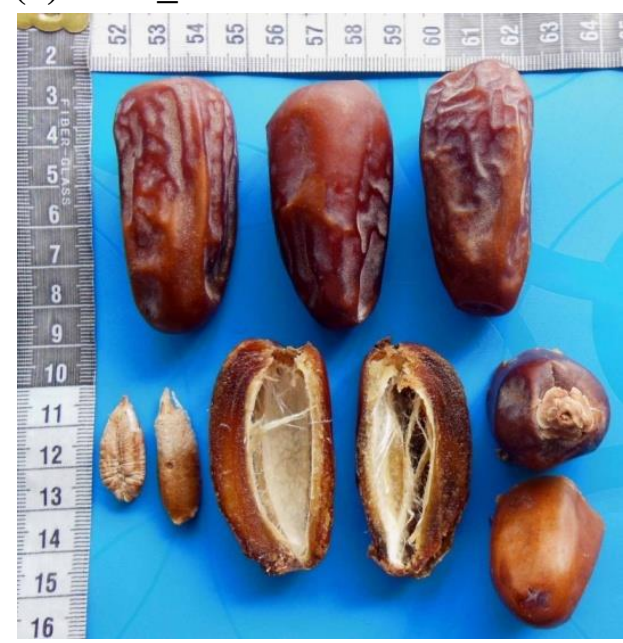

(b) Siwa_2

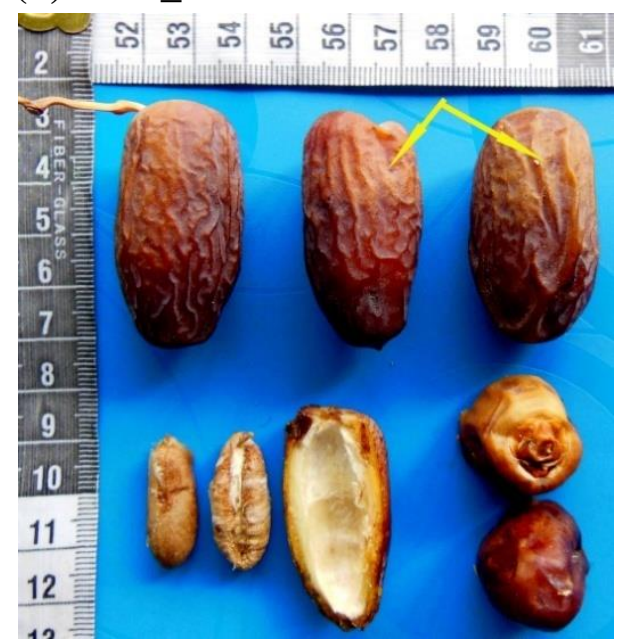

(c) Ghazal
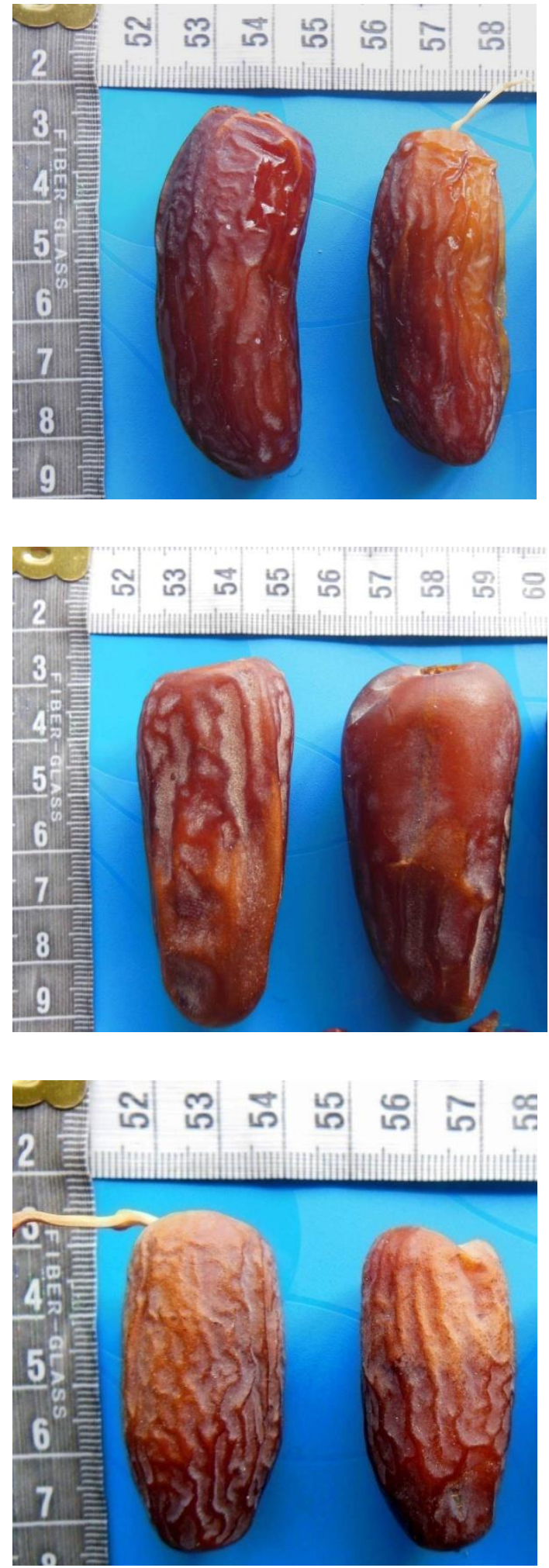

Fig.1. Fruit of the targeted superior genotypes of date palm from Siwa oasis at edible stage. 
Fig. 2. Pruning 4-6 fronds and getting the immature inflorescence of the superior genotype "Siwa_1" from Siwa oasis.

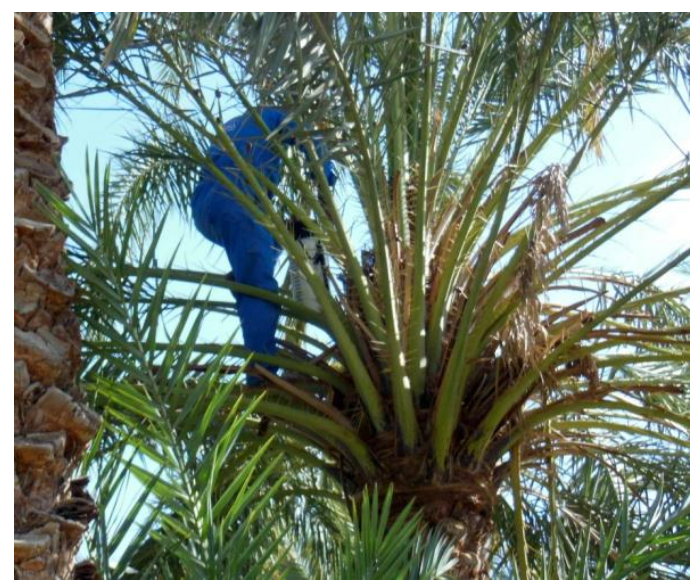

Fig.3. The excised immature spathe. The one which is appearing in the photo is about $50 \mathrm{~cm}$ long.

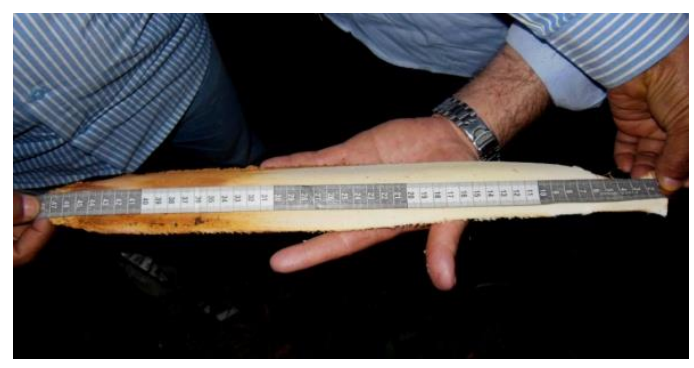

Fig.4. The parent tree after 3 months of immature spathe excision missing a single bunch and normally fruiting, Siwy cv.

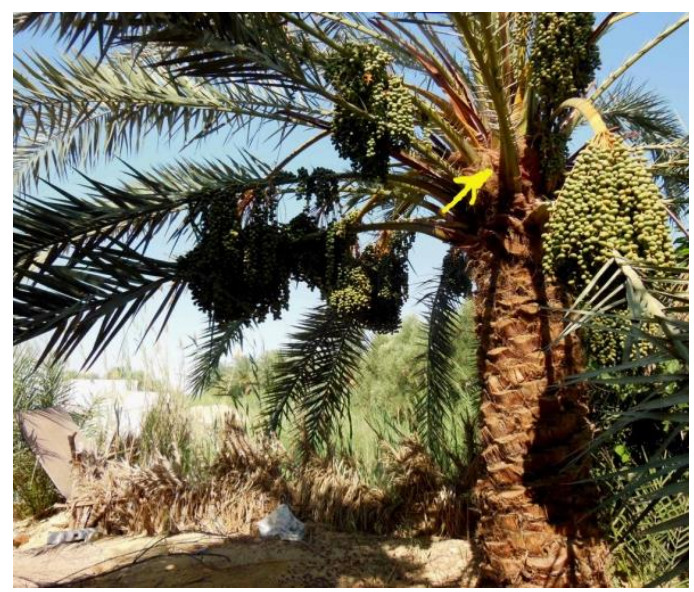

Fig. 5. Direct formation of the embryogenic calli on the initial explants of spikelets after 4 weeks in culture.

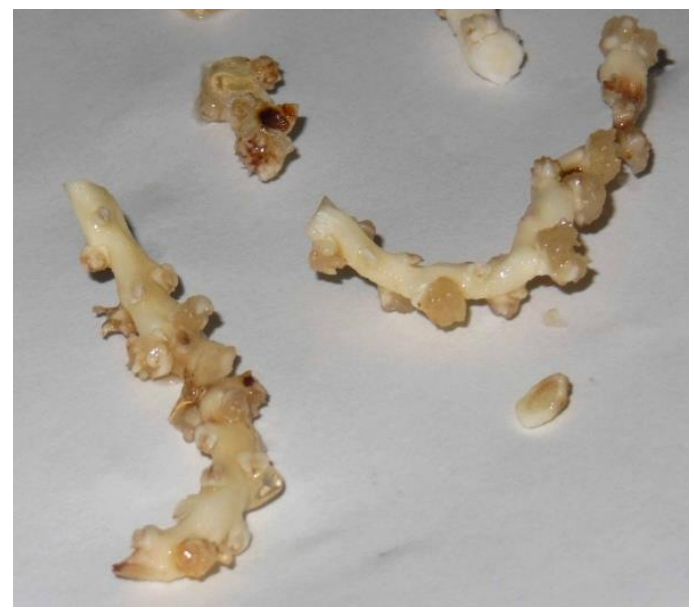


Fig.6. Differentiated multiple somatic embryos and shoots on the proliferation medium.

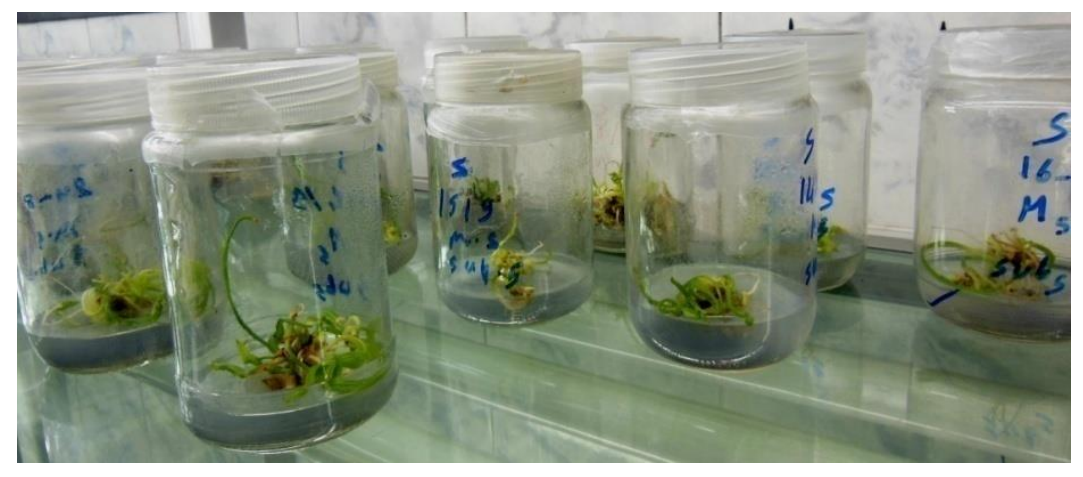

\section{Conclusions}

Connecting the carried-out steps in the current conservation program would help in giving impression on the timeline schedule required for whole process. Although the practical working is still going on in the following steps to get the ex-vitro plantlets and making fingerprinting.

\section{Acknowledgement}

This project was supported financially by the Science and Technology Development Fund (STDF), Egypt, Grant No. 5011.

\section{References}

A.O.A.C. (1995) 'Methods of analysis $13^{\text {th }}$ ed'., Association of official agricultural chemical Washington D.C.

Abahmane, L. (2007) 'Micropropagation of selected clones from inflorescence tissues and its role in the date palm (Phoenix dactylifera L.) improvement program'. Fourth symposium on date palm in Saudi Arabia, King Faisal University, Al-Hassa, 5-8 May, Abstracts Book, p 145

Abul-Soad, A.A, Emara, K.S., Mahdi, S.M. (2016) 'Somatic embryogenesis in Phoenix dactylifera L. using floral buds explants'. Acta Hortic. under publication.
Abul-Soad, A.A. (2011) 'Micropropagation of date palm using inflorescence explants', In: Jain SM, Al-Khayri JM, Johnson DV (eds.) pp. 91-118. Date palm biotechnology, Springer, Dordrecht.

Abul-Soad, A.A. (2012) 'Influence of inflorescence explant age and 2,4-D incubation period on somatic embryogenesis of date palm'. Emir $J$ Food Agr 24(5), pp. 434-443

Abul-Soad, A.A. and Mahdi, S.M. (2010) 'Commercial production of tissue culture date palm (Phoenix dactylifera L.) by inflorescence technique'. Journal of Genetic Engineering and Biotechnology. 8, pp. 39-44.

Abul-Soad, A.A., El-Sherbeny, N.R., Baker, S.I. (2004) 'Organogenesis in female inflorescence of date palm (Phoenix dactylifera L. $c v$. Zaghloul)'. In, pp. Proceedings of second international conference on date palm. Suez Canal University Faculty of Environmental Agricultural Sciences, El-Arish, Egypt, 6-8 Oct, pp 139-163.

Abul-Soad, A.A., Mahdi, S.M. (2010) 'Commercial production of tissue culture date palm (Phoenix dactylifera L.) by inflorescence technique'. J Genet Eng Biotech 8(2), pp. 39-44

Aslam, J., Khan, S.A., Cheruth, A.J., Mujib, A., Sharma, M.P. and Srivastava, P.S. (2011) 
'Somatic embryogenesis, scanning electron microscopy, histology and biochemical analysis at different developing stages of embryogenesis in six date palm (Phoenix dactylifera L.) cultivars'.. Saudi Journal of Biological Sciences 18, pp. 369-380

Drira, N. and Al-Shaary, A. (1993) 'Analysis of date palm female floral initials potentials by tissue culture'. In, pp. Proceedings of the third symposium on date palm, Saudi Arabia. King Faisal University, AlHassa, pp 161-170.

Eldin, A.F.M.Z. and Ibrahim, H.A. (2015) 'Some biochemical changes and activities of antioxidant enzymes in developing date palm somatic and zygotic embryos in vitro'. Annals of Agricultural Science. 60(1), pp. 121130.

El-Korchi, B. (2007) 'Large scale in vitro propagation of a rare and unique male date palm (Phoenix dactylifera L.) using inflorescence technique'. Acta Hort 736, pp. 243-254.

FAO (2017) 'Statistical databases'. http, pp. //faostat.fao.org (access: 01/06/2017).

Hussein, F., Dahshan, D.I., Gaafar, S.I. and Mousa, I.A. (1982) 'Evaluation of some seedling date palms grown at Ismailia Governorate'. Fac. Agric., Zagazig Univ. Res. Bull. 506.

Jatoi, M.A., Abul-Soad, A.A., Markhand, G.S., Solangi, N. (2015) 'Establishment of an efficient protocol for micropropagation of some Pakistani cultivars of date palm (Phoenix dactylifera L.) using novel inflorescence explants'. Pak. J. Bot., 47(5), pp. 1921-1927.

Mazri, M.A. and Meziani, R. (2015) 'Micropropagation of Date Palm': A Review. Cell Dev Biol 4, pp. 160. doi, pp. 10.4172/2168-9296.1000160
Moustafa, A.A., EI-Aidy, A.A. and EISammak, A.P. (1986) 'Evaluation of two seedling date palms grown in El-Wady EI-Gedid in comparison to standard cultivar "Heigazy"'. Proceeding of $2^{\text {nd }}$ symposium of the date palm in Saudia Arabic V01.II (pp. 153-161).

Ribeiro, J.M. and Teixeira, S.L. (2017) 'Clonagem in vitro de tamareira (Phoenix dactylifera L.). Petrolina: Embrapa Semiárido (Embrapa Semiárido. Comunicado Técnico, 170).

Ribeiro, J.M., Teixeira, S.L., de Souza, J.C., Ribeiro, B.L., Oliveira, A.B.N., Neto, T.F.C., Rios, L.S., Vieira, R.S. (2020) “In vitro response of date palm (Phoenix dactylifera L.) inflorescence explants to high 2iP and 2,4-D concentrations". AJCS 14(05), pp. 831-835.

Steel, R.G, Torrie, J.H. and Dickey, D. (1997) 'Principles and Procedures of Statistics: A Biometrical Approach'. The McGrawHill Co Inc. New York.

Zayed, E.M.M., El Din, A.F.M.Z., Manaf, H.H. and Abdelbar, O.H. (2016) 'Floral reversion of mature inflorescence of date palm in vitro'. Annals of Agricultural Science. 61(1), pp. 125-133. 